\title{
The Evaluation of Authentic Assessment Implementation in the Kurikulum 2013 at SD Negeri 067690 Medan
}

\author{
Deli Kesuma ${ }^{1}$, Edy Surya ${ }^{2}$, Edi Syahputra ${ }^{3}$ \\ ${ }^{1,2,3}$ State University of Medan (Unimed), Indonesia \\ , Indonesiadelikesuma1968@gmail.com
}

\begin{abstract}
Assessment certainly has challenges and problems, especially for teachers who directly implement the applicable curriculum. Therefore, this study aims to find out the extent of the implementation of authentic assessment models in kurikulum2013 which viewed from aspects of readiness, planning, and implementation of assessments conducted by teachers. This type of research is an evaluative descriptive study with quantitative approach. The study is conducted at SD Negeri 067690 Medan with total sample of 13 teachers. The results of this study indicate that the implementation of authentic assessment model in thekurikulum 2013at SD Negeri 067690 Medan, as follows: the percentage of evaluations to the readiness assessment shows good results with an average of $79.75 \%$, the percentage of evaluations of the assessment plan shows good results with an average of $77.43 \%$, and the percentage of evaluations of the implementation of the assessment shows good results with an average of $66.23 \%$. Based on these results, it can be concluded that the implementation of authentic assessment model in the kurikulum 2013at SD Negeri067690 Medan is unfavorable category. In line with implementation of the curriculum 2013.
\end{abstract}

Keywords: Evaluation; Authentic Assessment; kurikulum 2013

\section{Introduction}

Teachers have a significant role in the assessment process. The assessment of student learning outcomes is necessary in teaching and learning activities. By having assessment of learning outcomes, it can be seen how much the success of students in mastering the competencies or materials that have been taught by the teacher.

Assessment can be used as a reference to see the level of success or effectiveness of teachers in learning. Therefore, it must be done well, starting from the determination of instruments, preparation of instruments, review of instruments, conducting assessments, analyzing the results of assessments and follow-up programs of assessment results. Assessment of good learning outcomes will provide useful information in improving the quality of teaching and learning process. On the other hand, if an error occurs in the assessment of learning outcomes, there will be misinformation about the quality of the teaching and learning process and ultimately the educational objectives will not be achieved.

An education that does not produce quality graduates is not an investment in human resources, but a waste of costs, manpower and time. It is necessary to have an appropriate method for evaluating so that assessments made on students can provide complete information about students. The success of students in learning process can be measured by ainstrument that is in accordance with the learning objectives or competencies. Information obtained from the assessment must be comprehensive and have been carried out at the right times during and after learning process. This means that measurements must be made throughout the learning process undertaken by students.

Assessment and Evaluation has interrelated each other. Assessment is a process carried out through the steps of planning, preparation of assessment tools, and gathering information through a number of evidence that shows the achievement of student learning outcomes, 
processing, and use of information. Assessment can be carried out in various ways, such as the assessment of performance, attitude, written, project, product, portfolio, and self-appraisal.

The implementation of the kurikulum 2013 has changed the educational paradigm from behaviorist to constructivist, not only demanding changes in the learning process but also changes in carrying out assessments. The old paradigm in the assessment of learning is emphasized more on the results that tend to assess the ability of cognitive aspects, through the form of tests such as multiple choices, true or false, and match. The form of the test is considered to have failed to know the actual performance of students, regarding of the attitudes, skills, and knowledge of students is associated with their real life outside the school or community. In addition, the affective and psychomotor aspects are also ignored. Constructivism-based learning in learning assessment is not only intended to measure the level of cognitive abilities, but includes all aspects of the personality of students, such as moral, emotional, social development and other aspects of individual personality.

The kurikulum 2013 focuses on attitude competencies, knowledge, and skills. These three components are explicitly stated in the core competencies of students. The kurikulum 2013 regulates learning activities that prioritize the scientific approach of observing, asking, training, trying, reasoning, and communicating. These fundamental changes have an impact on the assessment system that is more directed to authentic assessment. This assessment is able to describe the improvement in student learning outcomes, both in the context of observing, reasoning, trying, and building networks or communicating. Authentic assessment is done by teachers in the form of classroom assessments through performance, portfolio, product, project, written, and self-assessment.

Based on observations in the field, it shows that the assessment system used by teachers is generally quite practical. It does not require a lot of energy, cost, and time. Authentic assessment requires more energy, cost, and time, so teachers are reluctant to use it. This behavior inhibits the achievement of the quality of learning in education.

The results of Pantiwati's research (2013: 2) about the profile of the grading system by the teacher shows that an objective form of written test dominates the instrument for measuring student learning outcomes, in addition to that the response of students also supports the form of written tests compared to other forms of assessment. Students do not like the assessment through critical analysis and protofolios that require studentshigh level thinking. This indicates that the situation of students at a low level has a negative impact on teacher teaching behavior. The teacher generally feels safe and finishes his job if he has carried out all curricular obligations even though the students do not understand what is taught.

Based on the results of an interview with Mr. Siagian, one of the teachers at SD Negeri 067690 Medan on Tuesday, March 16, 2019, it can be concluded that the implementation of the kurikulum 2013 in the school has been running for three years starting from 2017/2018 academic year. The headmaster always strives to prepare teachers to always be ready to implement the kurikulum 2013, as well as actively participate in the training conducted by the kurikulum 2013 supervisors. Problems that are often experienced by teachers in implementing the kurikulum 2013 are in the assessment section. In the process there are still many teachers who have difficulty assessing the results learner learners. This is related to the readiness of the teacher before starting the assessment, planning the assessment tools that they think are too many, then it affects the implementation of the assessment of student learning outcomes. 


\section{Review of Literature}

\subsection{Implementation of Kurikulum 2013}

National education functions to develop capabilities and shape the dignified character. National education aims to develop the potential of students to become human beings who believe and devote to God Almighty, have good character and health, knowledgeable, capable, creative, independent, and become democratic and responsible citizens. Therefore, making the figure of Indonesian graduates of formal basic education should have the following characteristics: (a) growing in faith and devotion to God Almighty, (b) growing attitude and ethics (polite, polite and civilized), (c) growing reasoning good (want to learn, want to know, like to read, have innovation, take initiative and be responsible), (d) grow communication/social skills (conscientious, cooperative, competitive), (e) grow awareness to protect the environment basic (Mulyasa, 2013: 21).

The implementation of the kurikulum 2013 has changed the educational paradigm from behaviorist to constructivist, not only demanding changes in the learning process but also changes in carrying out assessments. The old paradigm in the assessment of learning is more emphasized on the results that tend to assess the ability of cognitive aspects, through the form of tests such as multiple choices, true or false, and matchmaking. The affective and psychomotor aspects are also ignored. Constructivism-based learning in learning assessment is not only intended to measure the level of cognitive ability, but covers all aspects of the personality of students.

The characteristics of the kurikulum 2013 based on Regulation of education minister Number 70 of 2013 are designed with the following characteristics:

Develop a balance between developing spiritual and social attitudes, curiosity, creativity, collaboration with intellectual and psychomotor abilities

Schools are part of the community that provides planned learning experiences where students apply what is learned at school to the community and utilize the community as a source of learning

1. Develop attitudes, knowledge, and skills and apply them in various situations in schools and communities;

2. Give sufficient time to develop a variety of attitudes, knowledge, and skills;

3. Competencies are stated in the form of core class is further specified in the basic competencies of the subjects;

4. Class core competencies become organizing elements of basic competencies, where all basic competencies and learning processes are developed to achieve the competencies stated in core competencies;

5. Basic competence is developed based on the principle of accumulative, mutually reinforcing and enriched between subjects and levels of education (horizontal and vertical organizations).

Implementation of the kurikulum 2013 is the actualization of the curriculum in learning and the formation of competencies and character of students. This requires the activeness of teachers in creating and growing various activities in accordance with the plans that have been programmed. Teachers must realize that learning has a very complex nature because it involves pedagogical, psychological, and didactic aspects simultaneously. For this purpose, the teacher must have extensive knowledge about the types of learning, internal and external conditions of students, as well as how to make meaningful effective learning. 


\subsection{Authentic Assessment in the kurikulum 2013}

Assessment in the kurikulum 2013 refers to Regulation of Education Minister Number 66 of 2013 concerning Education Assessment Standards. Assessment Standards aim to guarantee: (1) planning assessment of students according to the competencies to be achieved and based on the principles of assessment, (2) implementation of student assessment in a professional, open, effective, efficient, and in accordance with the socio-cultural context, and (3) reporting the results of assessment of students in an objective, accountable, and informative manner. This assessment standard is prepared as a reference for educators, education units, and the government in the education unit for primary and secondary education.

The emphasis of assessment in the kurikulum 2013 is authentic assessment. Through the kurikulum 2013, authentic assessment becomes a serious emphasis where teachers in assessing student learning outcomes really pay attention to authentic assessment. Assessment is the process of gathering various data that can provide an overview of student learning development. The description of students' learning progress needs to be known by the teacher in order to ensure that students experience the correct learning process.

According Kunandar (2013: 35) authentic assessment is the activity of assessing students who emphasize what should be assessed, both the process and the results with a variety of assessment instruments tailored to the competency demands that exist in the Competency Standards or Core Competencies and Basic Competencies.Muchtar (2010: 72) explains Authentic Assessment is a process of gathering, reporting and using information about student learning outcomes by applying the principles of assessment, ongoing implementation, authentic evidence, accurate, and consistent as public accountability. Sani (2015) states that authentic assessment provides broad opportunities for students to show what they have mastered during the learning process, which focuses on goals, involves direct learning, builds collaboration, and instills higher levels of thinking.

Students in authentic assessment are asked to apply the concept or theory to the real world. Authentic means the actual state of the ability or skills possessed by students. Authentic assessment refers to the Benchmark Reference Assessment, namely the achievement of learning outcomes based on the position of the score obtained against the ideal score. Achievement of student competencies is not in context compared to other students, but compared to certain standards or criteria, namely the Minimum Mastery Criteria. So, teachers do not only assess the Basic Competency level, but also the Core Competency and Graduates Competency Standards.

Authentic assessment pays attention to the balance between the competency assessment of attitudes, knowledge, and skills that are adjusted to the development of the characteristics of students according to their level. Mastery of attitude competence has been embedded at the previous level. At lower levels of education, such as elementary schools, inculcation of attitude competencies should really be an emphasis and attention, so that when students later continue their education to a higher level, they have a foundation for a stronger attitude and a higher level to stay deepening their knowledge and skills competencies.

Kunandar (2013: 38) states the characteristics of authentic assessment are as follows: (1) Must measure all aspects of learning, namely performance and results or products; (2) Implemented during and after the learning process takes place; (3) Using various methods and sources; (4) Test is only one of the assessment data collection tools; (5) Tasks given to students must reflect the real life parts of students every day; and (6) Assessment must emphasize the depth of students' knowledge and expertise 


\subsection{Evaluation}

Sudijono (2006: 1) explains that evaluation is an action or a process to determine the value of something. Ekuntunto (2010: 1) views evaluation as a process of determining the results achieved by several activities planned to support the achievement of objectives. Evaluation is a process of describing, searching, and providing information that is very useful for decision makers in determining alternative decisions. It is an activity to find something valuable from something, in finding something that also includes finding information that is useful in assessing the existence, something program, production, procedures and alternative strategies proposed to achieve the stated goals (Arikunto, 2004: 1).

Law of the Republic of Indonesia Number 20 of 2003 concerning National Education System article 57 paragraph (1) states that the evaluation is carried out in the context of controlling the quality of education nationally as a form of accountability of education providers to interested parties.Based on some of the opinions, it can be concluded that evaluation is a planned activity to assess the achievement of a program that is beneficial for decision making. Evaluation is used to determine the extent to which a program runs so that steps can be determined.

\section{Research Methods}

This study uses descriptive evaluative research with a quantitative approach. Evaluative research is a design and evaluation procedure in collecting and analyzing data systematically to determine the value or benefits of an educational practice based on the results of measurement or data collection using certain standards or criteria used absolute or relative. In evaluation research, the criteria or benchmarks function to determine the level of achievement or success of an activity in a series of program implementation.

\subsection{The Objectives of Study}

The focus of research on evaluating the implementation of authentic assessment in the kurikulum 2013 at SD Negeri 067690 Medan, it is reviewed from: (1) Readiness assessment; (2) Planning an assessment; and (3) Implementation of the assessment. This research is conducted at at SD Negeri 067690 Medan, and the object of research is the teachers at the school.

\subsection{Data analysis technique}

Data analysis method used in this research is descriptive percentage analysis. Descriptive percentage analysis is a method used to process data obtained from respondents' answers through scoring with certain criteria. Descriptive percentages are intended to describe according to the percentage of respondents for each statement that has been answered. Based on the formulation of the problem and the objectives to be achieved in research, the type of research is descriptive quantitative

\subsection{Research Discussion}

This study intends to determine the readiness, planning, and implementation of assessments conducted by teachers at SD Negeri 067690 School Medan in implementing authentic assessment. The implementation of authentic assessment at SD Negeri 067690 Medan has been carried out along with the implementation of the kurikulum 2013. Scope assessed includes competency attitudes, knowledge competencies, and skills competencies. 
The Assessment atSD Negeri 067690 Medan is carried out in a variety of techniques for all basic competencies categorized in three aspects, namely attitudes, knowledge, and skills.

Based on the results of the evaluation of the readiness of the assessment, it shows good results with an average of $79.75 \%$. Based on these results, it can be concluded that the whole subject is not entirely ready to carry out authentic assessment in kurikulum 2013. The results of the questionnaire are strengthened by the results of interviews, document analysis, and observations. Through the results of the interview, it is known that the whole subject is not ready to carry out authentic assessment, where there are still some subjects who have not done it well.Based on the results of the document analysis the whole subject includes competencies, it is known that the evaluation percentage of the assessment plan shows good results with an average of $77.43 \%$. Regarding the determination of criteria, the subject states that they do not determine the indicators before conducting the assessment and the subject do not adjust the indicators with competence.

Technically, the teachers do not understand the ideal concept of the kurikulum 2013. The educators are still groping in translating the core of this kurikulum 2013. They are still very busy with efforts to improve their knowledge and skills competencies. The transition from one concept to another is very fast, regardless of whether students understand the content of the lessons that are part of the reasoning process as the core of the kurikulum 2013.

Based on observations of learning and interviews with classroom teachers, the implementation of authentic assessment in learning the curriculum2013atSD Negeri 067690 Medan has problems in terms of adjustments between the types of assessments with the characteristics of students, and the assessment procedures are more complicated. This can be seen from the percentage of evaluations of the implementation of the assessment showing good results with an average of $66.23 \%$. It is concluded that the evaluation of the assessment readiness shows good results with an average of $79.75 \%$, the percentage of evaluations of the assessment plan shows good results with an average of $77.43 \%$, and the percentage of evaluations of the implementation of the assessment shows good results with an average of $66.23 \%$.

The difficulty of assessing the competency of attitudes in each individual student is complicated, so it takes a long time, making an assessment of the attitude competency of the educator being not objective. It needs strengthening from the government to increase teacher awareness as a professional educator who is not only tasked with planning, guiding, educating, directing, but also carrying out the evaluation process of learning. The assessment system on education needs to involve parents and the community as a process and quality control of education. Parents and the community must realize that they also have a big role in providing positive and negative influences on students.

The problem that often arises is the adjustment between the types of assessments with the characteristics of students. Determining the type of assessment in authentic assessments in kurikulum 2013 is not a difficult thing because they are already available in the teacher's book. If there are students who feel they are not suitable with the type of assessment, it will cause problems. Students who feel unsuitable usually do not do the work for various reasons. Therefore, this cannot be tolerated because it will harm students and teachers. The diversity of characteristics of students must be harmonized so that students get optimal results. If there are less optimal results, the teacher must provide material deepening and improvement.

At the beginning of the implementation to carry out an appropriate procedural assessment it does feel heavy and difficult. The way to overcome the above problem is by holding teacher group work once a week to make a column early in the year. Teachers must also follow the 
upgrading of the kurikulum 2013and are always actively seeking out the latest information about authentic assessment in learning the kurikulum 2013.In order to realize the successful implementation of authentic assessment which is an important part of the kurikulum 2013, the government is conducting PLPG training and PPG education. The training is very helpful for teachers to understand how to implement authentic assessment both in theory and practice.

\section{Discussion}

Based on the data that has been obtained by the researcher, the implementation of authentic assessment in learning the kurikulum 2013 using techniques and instruments used to assess the four realms vary according to need. The assessment of attitude aspects is carried out through observation, self-assessment, and journal techniques. Observation assessment techniques with the instrument is in the form of an observation sheet. Observation assessment techniques is used because the data obtained are relatively objective but also requires careful attention from the teacher in his observations. In addition, teachers often use observation techniques because teachers tend to feel more suited to this assessment technique. The teacher know more about the characteristics of the students. The above technique is not too often used by the class teacher because to avoid lies. Commonly, this technique is used when the conditions of students are ready to do it. If not, the answers obtained are not exactly as expected because students only originate from answering. Journal assessment techniques can also be used as evidence to parents when there is a protest at any time. Journal can be used as a tool to control students. If negative events are considered above average, the school will give a warning through the classroom teacher. SD Negeri 067690 Medan is very concerned about the child's attitude problem because as proof of the successful implementation of the authentic assessment is not just a description in the report cards, but is reflected through the morals of the students.

Based on the results of the study, it can be concluded that Mrs. NB, and TH have used authentic assessment that assesses the competence of social attitudes, knowledge, and skills of students in learning the authentic implementation of kurikulum 2013. This is in accordance with the explanation in Permendikbud No. 104 on Learning Outcomes Basic Education according to Kunandar (2014: 52) which revealed that the scope of authentic assessment includes attitude competencies, knowledge, and skills.

Authentic assessment conducted by teachers in accordance with the opinion of Kunandar (2014: 138) states that teachers carry out an integrated assessment of the assessment is one component of learning, assessing in every aspect, and provide feedback on the results of the assessment. This supports the opinion of Kunandar (2014: 138) that two of teachers from that school (NB and TH )uses observation techniques to assess the display of students' attitudes, both social and spiritual attitudes. However, the two teachers do not use an assessment instrument in the form of a check list or scale.

This is in line with the results of Ramlan and Hermawan's research (2017). In fact, elementary school teachers in implementing the learning process are not ready to change the mindset of conventional teaching, namely teaching by only involving students' competencies from cognitive aspects and ignoring affective and psychomotor. This fact is obtained from a case study of elementary school teachers. This is also in accordance with the opinion of Kunandar (2014:126) states teacher needs to convey the competencies that students need to achieve, the assessment criteria, make observations, take notes, compare attitudes to rubrics, 
and determine the level of student achievement. Take notes, compare performances with rubrics, and determine the level of student achievement by the teacher at the end of the semester.

Class teachers at SD Negeri 067690 Medan in carrying out authentic assessments on each learning experience several obstacles, including: 1) There are too many types of assessment and there are too many students to be assessed so that teachers are not optimal in giving assessments and even teachers are too preoccupied with assessment then the material learning is not well delivered, 2) Administration in authentic assessment is too much so that the teacher feels the main difficulty on the report or report card, the teacher must present a summary of the assessment results for one semester in the form of a description using positive sentences.

Knowledge competency assessment is carried out by teachers (NB and $\mathrm{TH}$ ) in using written tests and assignments in the form of homework. This is in accordance with the explanation in Regulation Minister Education No. 104 concerning Evaluation of Learning Outcomes by Educators in Primary and Secondary Education, which states that the assessment of knowledge competencies can use written tests, observation of discussions, questions and answers, and conversations, as well as assignments. However, teachers do not write scoring guidelines to assess student work.

According to Hosnan (2014:396) the description instrument is equipped with a scoring guideline. This is used as a teacher's reference in determining the value achieved by students. Skill competency assessment is done by both teachers with performance. The instrument planned in the lesson plan is a checklist and rating scale. This is in accordance with Regulation of Education Minister Number 104 of 2014 concerning Results Assessment.

Kristiantari (2014) explains theoretically, the teachers already have an understanding of the kurikulum 2013. However, despite having an understanding of the kurikulum 2013, teachers still have difficulty in applying the kurikulum 2013. Motivation of teachers in implementing innovative learning is very high, but the it is not supported by facilities, the basis of having high expectations is related to the preparation of teachers to implement the kurikulum 2013, because this will have a positive impact on the quality of learning. Based on the results of this study, it is expected that there will be training conducted for teachers related to the kurikulum 2013 as well as the existence of supporting facilities and infrastructure in implementing the kurikulum 2013.

To observe the performance, checklist instrument or rating scale can be used, it is known that teaches at the school (NB and $\mathrm{TH}$ ) do not use the instruments that have been made. In addition, the two teachers also never submitted a rubric before carrying out assessments to students. This is not in accordance with the statement Kunandar (2014:268) which states that the teacher should submit the rubric before carrying out assessments to students. Because the teacher does not convey, the students do not know what aspects the teacher will assess.

The teacher's lack of understanding of the concept of authentic assessment is shown through interviews and questionnaires. Based on the results of interviews and questionnaires, some of teachers state that they do not understand the concept of authentic assessment well. In fact, they are still asking about the meaning of authentic assessments when the interview process takes place. It requires sufficient knowledge and understanding to apply authentic assessments properly. If knowledge and understanding have not yet been fulfilled, the application of assessment cannot be carried out properly.

In line with the opinion of Sani (2015) explains that in general, teachers do not understand and carry out authentic assessment in learning. Meanwhile, the results of this study indicate that only a small proportion of teachers do not understand the concept of authentic assessment 
well. All teachers also claim to have applied authentic assessment even though it is not perfect. These results indicate that an increase in teacher understanding and knowledge in a period of five years. Teachers are also increasingly open to innovation in education, especially in terms of assessment. This statement is also supported by the results of a questionnaire that shows that there are no teachers who only judge the rules of language. The teacher is currently assessing students' skills in thematic learning. Apart from the fact that teachers do not yet understand the concept of authentic assessment, there are teachers who claim to have carried out authentic assessments but feel that their application has not been maximized due to constraints faced. There are also teachers who claim to only carry out certain competencies.

Based on observations, all teachers observed have carried out authentic assessments, for example observations made on one of teacher (RB). In these observations, teachers make assessments. Teachers also assess students 'performances not only based on the knowledge held by students but also based on the results of students' performance practices. The data are collected by researchers from the results of observations of learning and interviews with classroom teachers, about the problems in the implementation of authentic assessment in learning the kurikulum 2013 at SD Negeri 067690 Medan. The terms of adjustments between the types of assessments with the characteristics of students, and assessment procedures are more complicated.

There are several obstacles in the implementation of learning of authentic assessment of 2013 curriculum at SD Negeri 067690 Medan. The inhibiting factor is to make lesson plans that take longer. To overcome this, some teachers at the school (LI, AB, NB, and TH) make study plan at home at night or during the holidays or at school during class hours.

The next obstacle is the allocation of learning time which is not always sufficient to complete a learning. To overcome this, the teacher will continue learning at the next meeting. The teacher also gives homework if the learning is not finished. In addition, the learning approach delivered by the two teachers is not in the order of observing, asking, trying, associating, and communicating, this is because not all learning activities always begin with observing. Therefore, the two teachers convey the steps of the learning approach in accordance with the learning activities undertaken. Furthermore, the integration of subjects in learning that integrates PJOK is not implemented. This is due to the limited number of physical education teachers possessed by SD Negeri 067690 Medan. To overcome this, PJOK learning is carried out separately, and scheduled separately. It has become an agreement at the school.

The next obstacle comes from students, namely the achievement of each different student, some are quick to master the material, and some need more guidance to understand the material presented. The efforts made by the teacher to overcome this are by giving attention, more guidance to children who have not reached basic competence, and assigning other students who are considered to have mastered to guide these students. The things that done by the teacher are the efforts of the teacher in providing students the opportunity to develop abilities based on differences in the individual abilities of students. In accordance with the principles of curriculum development stated by Daryanto (2014: 3) curriculum is developed by giving students the opportunity to develop differences in abilities and interests.

Evaluation is also one of the obstacles, especially in the process of carrying out assessments and processing values that require a long time. To overcome this, SD Negeri 067690 Medan already has a special application for processing grades, and making student report cards. The last obstacle comes from parents. In addition to supporting the implementation of learning, parents' understanding of assessment students who use descriptions also makes the teacher must explain the purpose of the qualitative assessment 
conducted. Even though the teacher has given an explanation and distributed the value conversion paper during the report card distribution. In addition, thematic learning that requires collaboration between students and parents at home often raises questions from parents.

The description of the obstacles in carrying out learning in the implementation of authentic assessment of kurikulum 2013, supports the opinion of Pantiwati (2013: 4) who states that the obstacles in implementing authentic assessment learning in kurikulum 2013can be caused by teacher factors (knowledge, qualifications of subject matter, and knowledge), and contextual factors such as administrative policies, curriculum guidelines, assessment and reporting processes, and school traditions (Iif Khoiru Ahmadi and Sofan Amri, 2014: 101).

The way to overcome the above problem is by holding teacher group work once a week to make the column early in the year. The teacher must also follow the upgrading of the kurikulum 2013 and always actively seek out the latest information about authentic assessment in learning the kurikulum 2013. The solutions provided by the teacher are appropriate because by recognizing the characteristics. It will be easy to determine the type of assessment and if students do not feel burdened with the task then an atmosphere of competition will be created to achieve the best value. The problem of difficult assessment procedures will be overcome if there is communication between the teacher and actively looking for the latest information about authentic assessment will make it easier for teachers to better understand the assessment procedures.

\section{Conclusions}

Based on the results obtained from research on evaluating the implementation of authentic assessment and research on the analysis of teacher readiness in implementing authentic assessment at SD Negeri 067690 Medan, it can be concluded that the analysis of teacher readiness in implementing authentic assessment is still not optimal, this is shown in the uneven dissemination and training for teachers. The effectiveness of the kurikulum 2013 training is not yet effective, the teachers are not yet maximized in the implementation of learning in kurikulum 2013, namely limited time management, incomplete facilities and infrastructure, and assessments that are considered still very difficult.

The teacher has tried to do the steps in applying authentic assessment appropriately. The steps of applying authentic assessment conducted by teachers include determining standards, determining authentic assessment models, determining criteria, making rubrics, socializing to students, carrying out assessments, and giving scores and grades. It is known that the teacher still experiences various kinds of obstacles in applying authentic assessment. Constraints in question include time constraints, limited facilities and infrastructure, difficulty in applying authentic assessment to certain competencies, difficulty in applying certain authentic assessment models, and student constraints.

\section{References}

Ahmadi, lifkhoiru and Amri, Sofan. (2014). Pengembangan Bahan Ajar \& Model Pembelajaran Tematik Integratif. Jakarta: PT Prestasi Pustaka raya.

Ariestuti, Putu Dewi, I Wayan Darsana, and Rini Kristiantari et al. 2014. "Penerapan Pendekatan Contextual Teaching and Learning (CTL) untuk Meningkatkan Keaktifan dan Hasil Belajar IPA Siswa Kelas VI SDN 3 Tonja Tahun Ajaran 2014/2015. ’Jurnal Mimbar PGSD Universitas Pendidikan Ganesha2 (1). (http://ejournal.undiksha.ac.id/index.php/JJPGSD/article/viewFile/4098/3233). 
Arikunto, Suharsimi. (2010). Prosedur Penelitian Suatu Pendekatan Praktek. Jakarta: Rineka Cipta.

Arikunto, Suharsimi. (2004). Prosedur Penelitian. Jakarta: Rineka Cipta.

Burhan, Nurgiyantoro.(2009). Penilaian Pengajaran Bahasa.Yogyakarta: BPFE.

Daryanto. (2014). Pendekatan Pembelajaran Saintifik Kurikulum 2013. Yogyakarta: Penerbit Gava Media.

Hosnan, M. (2014). Pendekatan Saintifik dan Kontekstual dalam Pembelajaran Abad 21. Bogor: Ghalia Indonesia.

Kunandar. (2013). Penilaian Autentik (Penilaian Hasil Belajar Peserta Didik berdasarkan Kurikulum 2013). Raja Grafindo Persada: Jakarta.

Kunandar. (2014). Penilaian Autentik (Penilaian Hasil Belajar Peserta Didik Berdasarkan Kurikulum 2013. Jakarta: Raja Grafindo Persada.

Mulyasa, E. 2013.Pengembangan dan Implementasi Kurikulum 2013. Bandung: PT Remaja Rosdakarya.

Pantiwati, Yuni. (2013). Hakekat Asesmen Autentik dan Penerapannya dalam Pembelajaran Biologi, dalam JEMS No. 1. Malang: Universitas Muhammadiyah Malang.

Permendikbud No. 70 tahun 2013 tentang Kerangka Dasar dan Struktur Kurikulum SMK$M A K$.

Permendikbud Nomor 66 Tahun 2013 tentang Standar Penilaian Pendidikan.

Sani, Ridwan Abdulloh. (2015). Pembelajaran Saintifik untuk Implementasi Kurikulum 2013. Jakarta: BumiAksara.

Sudijono, Anas. (2006). Pengantar Statistik Pendidikan. Jakarta: PT. Raja Grafindo Persada. 